\title{
RECOGNITION AND DISSIMULATION
}

\section{Nationalism and Genre in James Clarence Mangan's 'The Lovely Land'}

James Clarence Mangan has been celebrated by James Joyce and W. B. Yeats as one of the preeminent Irish writers of the nineteenth century. This essay interprets his poem 'The Lovely Land', first printed in The Nation on 18 July 1846, in terms of genre and nationalism. In an early Irish example of ekphrasis, the poem stages a rhetorical misreading where the speaker mistakes an unnamed Irish landscape of Daniel Maclise's for a painting by Veronese or Poussin. Where - among his English and German Romantic predecessors - might Mangan have found a precedent for the poem's treatment of landscape? And how does the colonial relationship between Ireland and England fit in with the poem's complex manoeuvring of different national iconographies? In seeking to answer these questions, this essay looks to further the 'mapping' of Mangan's position in Romanticism as an international movement.

K E Y W O R D S James Clarence Mangan, Genre, Nationalism, Ekphrasis, The Nation.

James Clarence Mangan (1803-49) (ill. 1) published the poem 'The Lovely Land' in the Dublin-based newspaper The Nation on 18 July 1846. The Nation ${ }^{1}$ was far from being an innocuous vehicle for the poem. As a leading Irish nationalist newspaper at the time, fighting for the Repeal of the Union with England, The Nation featured key figures of the Young Ireland movement - including its three founders Charles Gavan Duffy, Thomas Davis, and John Dillon, as well as the later key figure John Mitchel - who were friends of Mangan's. Later, in the period between July 1848 and September 1849 , The Nation would be suppressed by the British government, due to its proclamation of outspokenly nationalist views - often with a revolutionary or violent tenor. ${ }^{2}$ This context is relevant to the investigation into how this poem overlays the national with the international. Part of the object of this reading will be to show how the poem articulates a nationalist position, in the context of the Young Ireland movement and other writings of The Nation, through engaging with foreign examples and precedents of not only a visual but also a verbal character. An important precedent is provided by Romanticism. There is no overall consensus concerning Mangan's relationship to Romanticism: while some critics acknowledge the value of for instance 


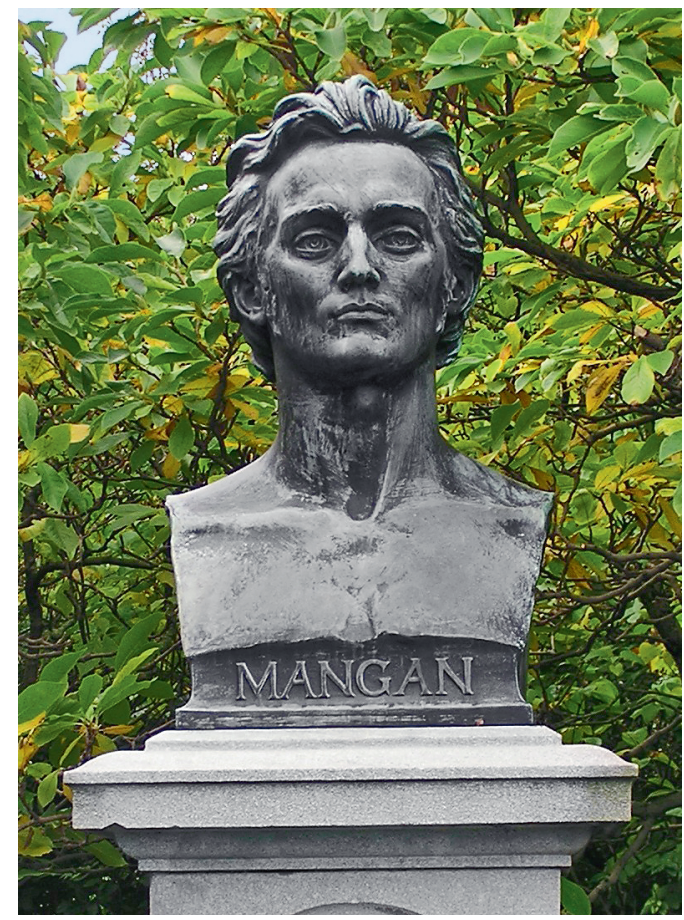

III. 1 [Oliver Sheppard, Bust of James Clarence Mangan. Photo: David M. Jensen, Dublin, Ireland.]

Byron and German Romanticism for his writings, he has also been described as 'in many ways the antithesis of the Romantic poet, at least in its Wordsworthian guise.' Another concern here will be how the ekphrasis of the poem interacts with other genres - such as the pastoral, translation, and the oath - in a complex fashion.

'The Lovely Land' consists of ten quatrains with embracing rhymes, each stanza including three tetrameter lines followed by a trimeter. After two stanzas devoted to an enthusiastically responsive description of a landscape painting, stanzas three through five speculate whether that painting is the work of the Italian Paolo Veronese or the French Claude Poussin. Subsequently, the speaker muses on the supernatural associations evoked by the landscape, and his own desire to attain transcendence through his immersion into it. The final stanzas - stanzas eight through ten - overturn the earlier attribution of the painting to foreign masters: identifying it as an Irish landscape by Mangan's countryman Daniel Maclise (1806-1870), the speaker celebrates his homeland and expresses a strong commitment to his nation's future cause.

The poem's claim to be responding to a landscape by Maclise makes it of particular interest as a forerunner to a rich tradition of ekphrastic poems in Irish literature. A veritable deluge of ekphrastic works in recent Irish poetry caused the critic Edna Longley to title her influential essay on the topic 'No More Poems about Paintings?'4 The accomplishments of twentieth-century figures such as W. B. Yeats, John Hewitt, and Derek Mahon in this genre are considerable, but there is little evidence of a similar poetic interest in the visual arts, in an Irish 
context, if one goes back to the previous century. Partly this may have been the result of the centrality of a rich oral (rather than visual) tradition of bardic verse in Ireland, and partly the longstanding lack of access to major works of art in the country may be to blame. The National Gallery in Dublin first opened its doors in 1864, and other important galleries - including the Municipal Gallery, for which Yeats played an important role - were established much later. This does not mean that the 1840 os were devoid of interest in the visual arts. In the pages of The Nation, one can for instance read letters written by the painter Henry O'Neill, arguing on behalf of the Royal Irish Art Union that the artistic example provided by Maclise and other Irish artists shows that the time is right to support institutions, galleries, and exhibitions that will foster a native Irish tradition in the arts. There is also a growing interest in the relationship between literature and art, as evidenced for instance by an anonymous two-part article on visual illustration of literary texts printed in The Nation on 29 November and 6 December 1845 . Entitled 'Maclise's Illustrations of Moore', the article uses the recent publication of a book containing Thomas Moore's Melodies accompanied by illustrations by Maclise as the occasion for a principled discussion of a relation between these arts. Through the work of W. J. T. Mitchell and others, we have now grown familiar with the idea that a paragonal relationship - a competitive one, where the different forms vie for supremacy and primordial status - has been a staple of much interaction between the arts through the ages. ${ }^{5}$ Such a relationship is also in evidence in this article, which proclaims that recent popularity of book illustration is a symptom that the 'pencil, the brush, and the graver, threaten soon to dethrone the pen'. ${ }^{6}$ Book illustrations are a mistaken pursuit, readers are told, since such work neglects the fact that literature is fundamentally different - and indeed also placed at a higher level - than the visual arts. The anonymous contributor to The Nation hedges his bets, however, by also arguing that all of the main arts have an absolute value as long as they stand on their own. Transgressing the borders between the arts is (apart from a few minor examples) pernicious, as this leads to relations of subservience: ' $[\mathrm{T}]$ he most exquisite professional illustrator of ancient or modern poetry ... abandons his charter of equality so long as he assumes the office of mere interpreter and decorator." After various digressions and swerves of argument, the writer ends by lamenting that Ireland's best artists have emigrated to London: Maclise and Moore may be 'exiled', but they are 'neither forgotten nor forgetful'.'

\section{Maclise and the Romantic Precedent}

The Nation article foreshadows key aspects of Mangan's poem, which would be published in the same weekly a few months later. The complex link between the visual and verbal arts, the relationship between Irish art and its native soil, and the value of a supportive or secondary work of art: all of these are issues that will recur in our reading of 'The Lovely Land'. More covertly, the reclaiming of a lapsed - or potentially lapsing - expatriate may also be at stake. It has proven 


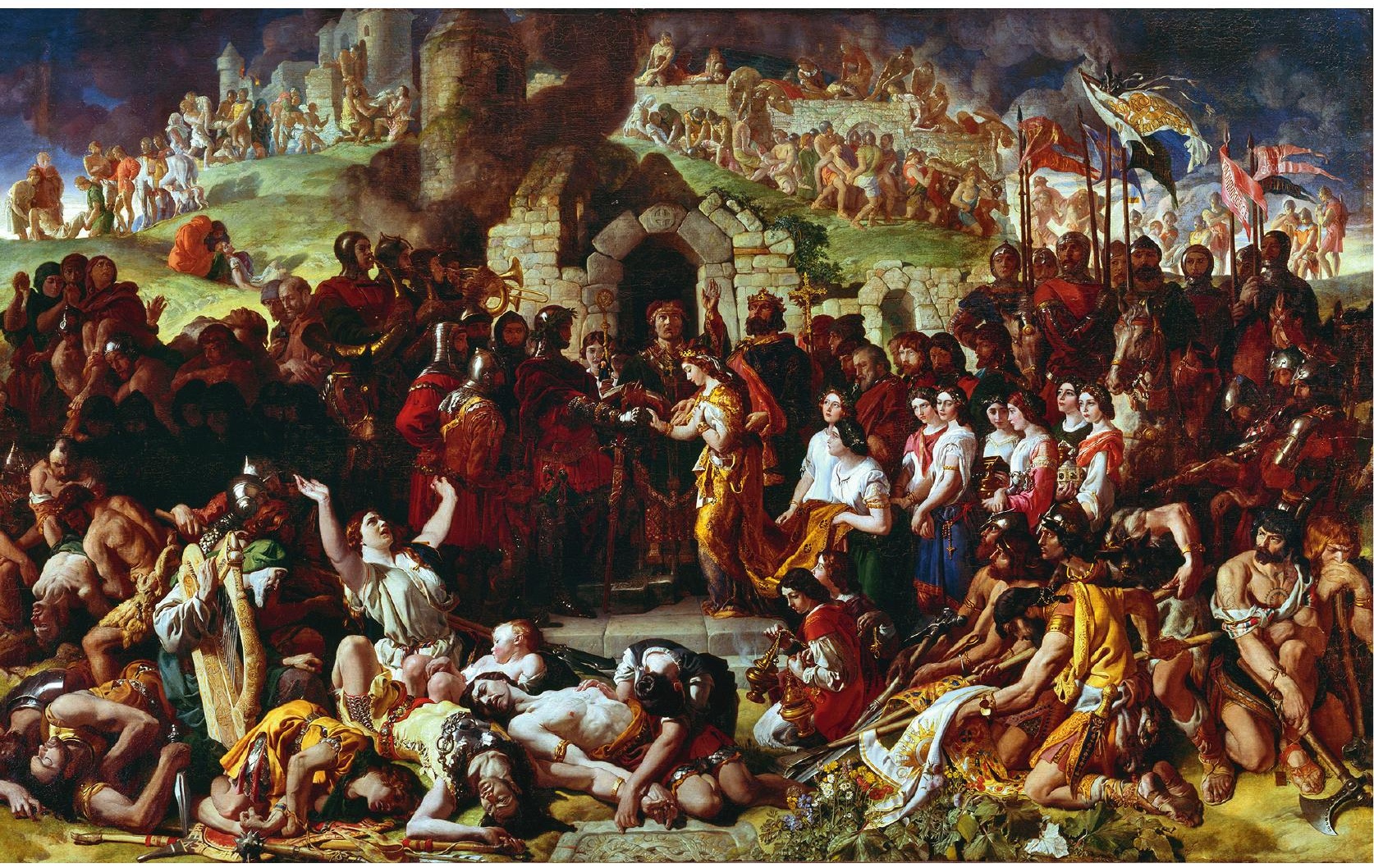

III. 2 Daniel Maclise, The Marriage of Strongbow and Aoife, 1854.

Oil on canvas, $315 \times 513 \mathrm{~cm}$. National Gallery of Ireland. Photo (c) National Gallery of Ireland.]

impossible for modern scholarship to identify any given landscape by Maclise that fits the description given in Mangan's poem. Maclise's most famous painting with an explicitly Irish theme and setting, The Marriage of Strongbow and Aoife, was first exhibited at the Royal Academy in London in 1854 - and hardly fits the bill anyway (ill. 2).

Early drawings made by Maclise during a tour of Ireland in the 1820 - such as 'The Valley of the Seven Churches', based on the Glendalough site - might have been seen by Mangan, but again there is no close correspondence with the poem (ill. 3).

Yet even if one cannot locate any simple pre-textual basis for 'The Lovely Land', there are known factors that explain, at least in part, why Mangan would wish to evoke Maclise at this point in time. Maclise's previously mentioned illustrations to Moore's Melodies could well have provided an impetus. In The Nation, this 'noble book' was said to include 'the songs of our greatest lyrist, illustrated by our greatest painter', ${ }^{9}$ and the publication may indeed also have suggested to Mangan that Maclise deserved the imprimatur of being the representative Irish artist of his time. We know that Mangan's appreciation of this artist was no pass- 


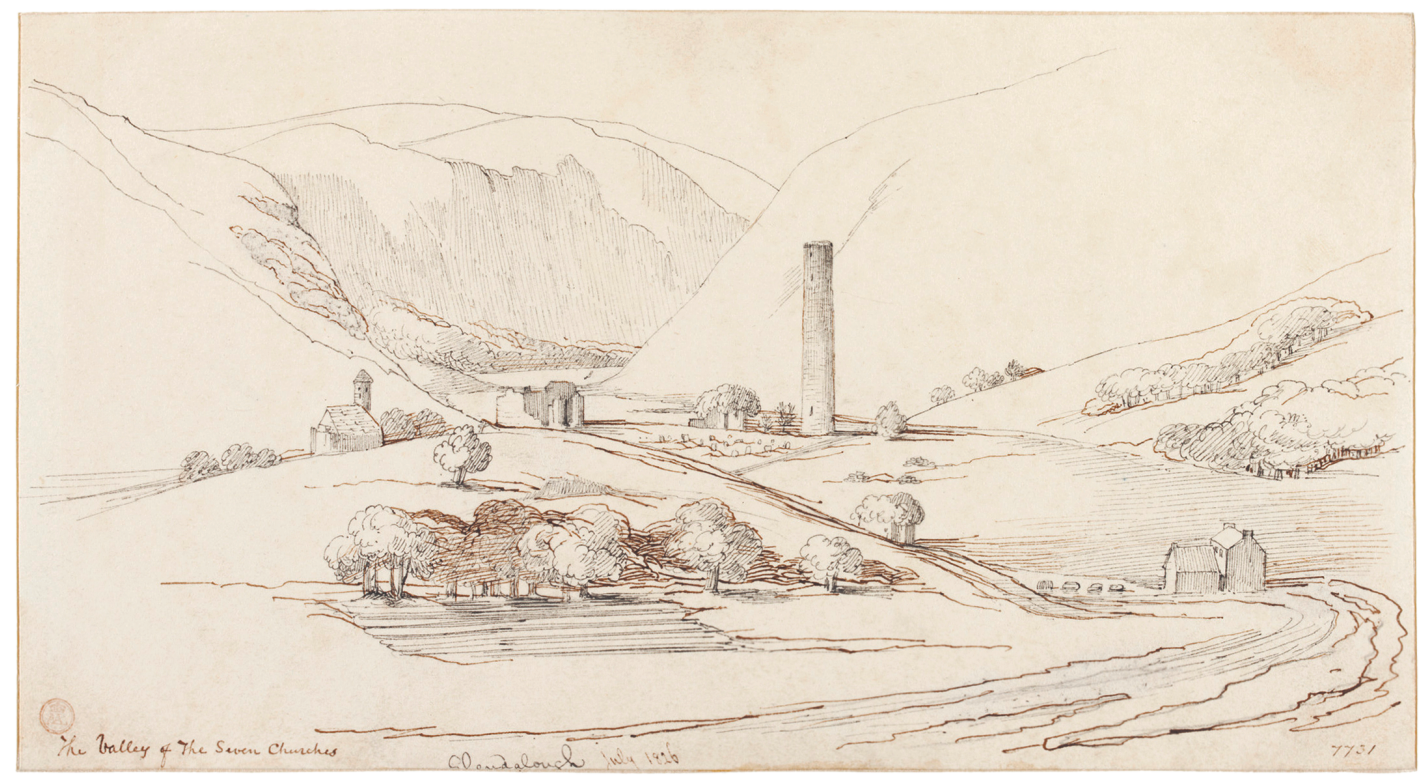

III. 3 [Daniel Maclise, The Valley of the Seven Churches, 1826.

Pencil and ink on paper, $13 \times 24 \mathrm{~cm}$. (c) The Victoria and Albert Museum, London.]

ing thing: In 1849, which turned out to be the last year of his life, the poet described Maclise as the 'most imaginative painter of the age'. ${ }^{10}$ I will return to this issue towards the end of this article, as there are complicating factors that make Mangan's choice of painter somewhat mysterious.

The speaker makes a strong statement in the penultimate stanza of Mangan's poem, claiming that 'through Maclise's eyes / I first see thee, Ireland!' The artwork does not simply replicate or represent the nation, but rather something far more challenging and fundamental: it shows the nation that is Ireland. Literature's part is presumably to comment and elucidate, where art provides the immediate sensory vision of national identity. There is a claim to dynamism and originary power in these lines, which is in agreement with Jean-Luc Nancy's Heidegger-inspired formulation of non-representational being as a 'birth to presence. ${ }^{11}$ Maclise has, as it were, provided an act of midwifery that enables the birth of the idea of the nation. This links up with the beginning of Mangan's poem, which celebrates the landscape as a 'Glorious birth of Mind and colour'. That opening line might be conceived of as hedging its bets: for why are both mind and colour, both a suprasensible and a sensible embodiment, evoked? This formulation is tacitly echoed by Mangan a couple of years later, when he in 'The Tribune's Hymn for Pentecost' describes Ireland as 'The Golden House of Light and Intellect'. ${ }^{12}$ The emphasis on mind would seem to contradict the author of 'Maclise's Illustrations of Moore', who had denied the visual arts recourse to the highest levels of thought. Mangan's wording can be explained via Romantic poetics, and its emphasis on the mental faculties of the artist. As with many of the 
Romantics, the mind tends to be conceived of by Mangan as a transcendental faculty that goes beyond any parochial or national interest. Thus, his posthumously published 'Consolation and Counsel' takes his countrymen to task for 'the severing bar / That insulates you now from Europe's Mind. ${ }^{13}$ The prose commentary to his oriental translations in the September 1837 issue of the Dublin University Magazine expresses this tension in more principled terms:

The mind, to be sure, properly to speak, is without a home on the earth. Ancestral glories, genealogical charts, and the like imprescriptible indescriptibles [sic] are favorite subjects with the composite being Man, who also goes now and then the length of dying in idea for his fatherland - but for Mind - it is restless, rebellious - a vagrant whose barren tracts are by no means confined to the space between Dan and Beersheba. It lives rather out of the world. ${ }^{14}$

If one adds to this emphasis on transcendental placelessness Mangan's frequentlyexpressed lack of interest in natural surroundings, then one gains something of a sense of the anomalous position 'The Lovely Land' has in his oeuvre. For this is not a typical poem by Mangan, of whom Yeats wrote: 'Outer things were only to him mere symbols to express his inmost and desperate heart. Nurtured and schooled in grimy back streets of Dublin, woods and rivers were not for him. ${ }^{15}$ The plot thickens if one takes into account the date of composition: 1846 is not the most propitious time for idyllic eulogies of the Irish landscape. In Irish Pastoral, Oona Frawley has claimed that during the first decades of the nineteenth century the 'general Irish population' put up a 'resistance to the romanticization of nature that had taken place in England'. ${ }^{16}$ This may or may not be a too simple generalization, but it is not hard to concur when she claims that the famine certainly exacerbated any sense of disharmony there might have been earlier between human lives in Ireland and their surrounding natural landscape. In her biography of the poet, Ellen Shannon-Mangan points to the close connection between 'The Lovely Land' and Mangan's later poem entitled simply 'The Famine. ${ }^{17}$ The later poem starts by evoking a blessed past, 'when thoughts and violets bloomed - / When skies were bright, and air was bland and warm', before concentrating on the subsequent despair attendant to the time when 'a blight fell on the land' and the 'soil, heaven-blasted, yielded food no more'. ${ }^{18}$

By the summer of 1846 , the potato blight had already arrived in Ireland, with heart-breaking consequences. ${ }^{19}$ Nevertheless, this seems not to be a factor in the poem - at least if one does not read the sixth stanza reference to the landscape being 'Peopled not by men, but fays' as ironic. Passages in 'The Lovely Land' draw clearly on Romantic and pre-Romantic precedents with regard to the celebration of landscape. The beginning of Mangan's poem is for instance evocative of the 'Intimations' ode. In the first stanza the 'radiant face' of the landscape, which also is a 'Glorious birth of Mind and colour', seems reminiscent of line sixteen of Wordsworth's poem: 'The sunshine is a glorious birth'.20 The second stanza is pitched even closer to the precedent of the Lake Poet, as lines one to four of 
Wordsworth's ode famously run: 'There was a time when meadow, grove, and stream, / The earth, and every common sight, / To me did seem / Apparelled in celestial light.' Mangan has a related 'eam'-rhyme in 'beaming'/dreaming', and follows this up with 'stream' / 'dream' in his fourth stanza. Wordsworth's 'meadow, grove and stream' is strongly echoed by 'mountain, mead and grove', while Mangan's 'divinest light' responds to 'celestial light' in what are closely matched lines. Another influence is evident in the somewhat looser echoes of Friedrich Schiller in the middle part of 'The Lovely Land'. Schiller was one of the poets Mangan most frequently translated, and when the Irishman describes his landscape as an ancient one, associated with supernatural beings and legendary tales, we are not far from the German poet's 'Die Götter Griechenlands'. ${ }^{21}$ Lines 145-8 of Schiller's celebrated poem ('Kehre wieder / holdes Blüthenalter der Natur! / Ach! Nur in dem Feenland der Lieder / lebt deine goldne Spur') would, for instance, seem to overlap quite closely with Mangan's sixth stanza: 'This is some rare clime so olden, / Peopled, not by men, but fays; / Some lone land of genii days, / Storyful and golden!' In the prose commentary to his German translations in the October 1835 issue of the Dublin University Magazine, Mangan claimed that 'the leading characteristic of German Poetry' was an overly adventurous 'attempt to assimilate the creations of the ideal with the forms of the actual world'. ${ }^{22}$ Here, over a decade later, he seems to not only be following - but also outdoing - Schiller in the forging of links between landscape and a supernatural bliss associated with faery beings.

At once one brings a combination of Greek mythology and pastoral nostalgia into the ambit of Mangan's poem, it becomes tempting to relate it to that most influential performance of ekphrasis in British Romantic poetry, John Keats's 'Ode on a Grecian Urn'. Keats's poem has been an inescapable reference point for many subsequent works in this genre, and through his numerous allusions to key figures (including Wordsworth, Shelley, Byron, and indeed also Keats) we know Mangan was quite conscious of his English Romantic forebears. When Mangan's seventh stanza expresses a wish 'to wander / One bright year through such a land' - or even to be content with standing 'one hour' on the hills of the painting - we encounter structures of desire that might seem evocative of Keats's contrast between art and the dissatisfactions of 'All breathing human passion' (1. 28). ${ }^{23}$ Apart from this, though, the poems do not seem particularly similar - and certainly 'The Lovely Land' is far removed from both the questioning distance and epigrammatic pithiness characteristic of 'Ode on a Grecian Urn'.

\section{Translation, Landscape, and the Irish Future}

The Victorian poet Francis Thompson once pointed out that Mangan 'needed a suggestion or a model to set his genius working, ${ }^{24}$ and ekphrasis is a genre - like that of translation - that institutionalizes such a modus operandi. The kind of inter-artistic relationships of subservience or dependency decried by the author of 'Maclise's Illustrations of Moore' must at least be negotiated within the genre. 
The ekphrastic text necessarily bases itself upon a preceding visual representation, however freely it may relate to that precedent. In the case of 'The Lovely Land', we are unable to gain a clear sense of what sort of liberties Mangan may or may not be taking. If indeed the landscape of Maclise's is a fictional one, invented by Mangan for the purpose of writing his poem, then we are dealing with an example of what James Heffernan has termed 'notional ekphrasis' - an illustrious subgenre that includes Homer's description of the shield of Achilles in The Illiad. ${ }^{25}$ We are in fact ignorant, though, of whether or not Mangan's poem is actually relating to an existing original. In this respect, 'The Lovely Land' replicates a familiar scenario for Mangan's readers, who must often have been uncertain whether his purported translations were following a German or Oriental original, or whether they were in fact original poems. ${ }^{26}$ Mangan did not hide the circumstances that fostered such uncertainty: in a late autobiographical sketch, posthumously published in the Irishman, he describes himself as having 'perpetrated a great many singular literary sins, which, taken together, ... would appear to be "the antithesis of plagiarism",.27

Regardless of whether Mangan had a concrete painting by Maclise in mind or not, his poem would seem to relate closely to the underlying structures of translation - as is made evident by the references to foreign masters of painting in stanzas three and four. The references to Poussin and Veronese are essential to the structure of misrecognition followed by insight constructed within the poem (ill. 4). ${ }^{28}$

One can read this relation in many ways, but in any case it relates closely to translation: where translation rearticulates the foreign text as a native one, ${ }^{29}$ 'The Lovely Land' uncovers that the foreign image is in reality a native one. The similarity is even closer for practices of translation that involve dissimulation, as we know to be the fact with Mangan's fictionalised translations. This aspect of dissimulation is acknowledged in David Lloyd's analysis of what he shows to be the underlying, refractory logic of Mangan's translations, whereby 'one tries to put oneself into foreign situations but really only appropriates and reproduces the foreign in one's own sense. ${ }^{30}$

This does not explain why exactly Veronese and Poussin are singled out in this poem. In his introduction to a recent exhibition devoted to 'Landscape and Irish Identity' at the Crawford Art Gallery in Cork, Peter Murray points out that in the eighteenth century Irish landscapes were typically interpreted through the prism provided by the Italian landscapes of artists such as Claude Lorrain and Salvatore Rosa. ${ }^{31}$ Mangan's poem seems to be following this example, but also pointedly updating it through a corrective gesture of Romantic nationalism. Even while defending the Irish landscape against neglect and ignorance, the poem's comparison might also be seen as elevating that very same landscape through association with the classical ideal of Italy. The absence of any reference to English landscape is notable, and might be comprehended in relation to Mangan's adoption of a more aggressively anti-British rhetoric late in his career. Less than a month after the publication of 'The Lovely Land', The Nation published Mangan's translation 


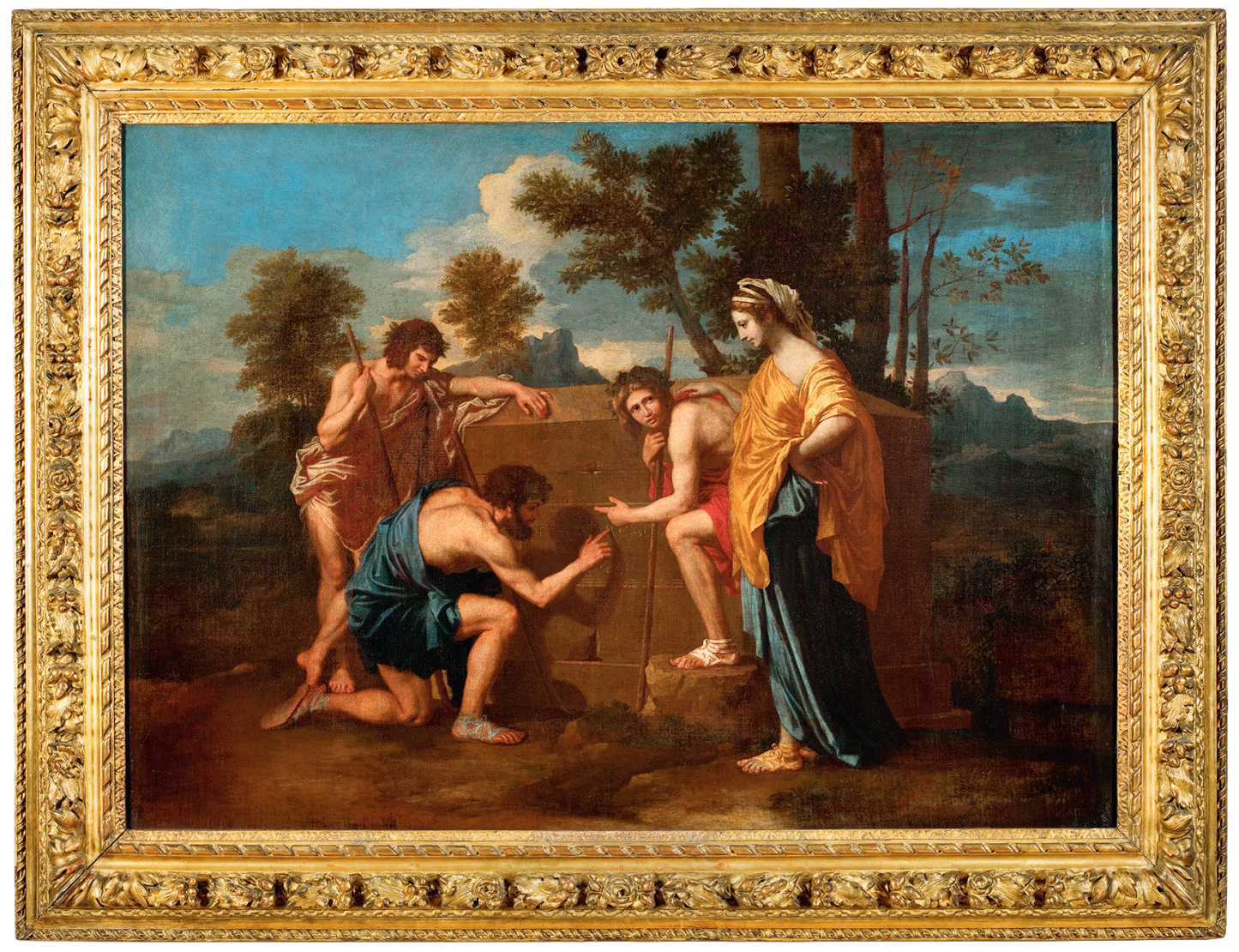

III. 4 [Nicolas Poussin, Les bergers d'Arcadie, dit aussi Et in Arcadia ego, ca. 1638-40.

Oil on canvas, $85 \times 121 \mathrm{~cm}$. (C) Musée du Louvre,

Dist. RMN-Grand Palais / Angèle Dequier.]

'Lament over the Ruins of the Abbey of Teach Mologa', which denounced the effects of 'brutal England's power'. ${ }^{32}$

The latter poem is interesting, in this context, for yet another reason: its stanzaic form is closely related to that of 'The Lovely Land'. Although there are differences, we have in both cases an abba quatrain, with a shorter final line. This stanzaic pattern is found in two other of Mangan's Irish translations - 'O Hussey's Ode to the Maguire' (also 1846) and 'Owen Reilly: a Keen' (1847) - published during roughly the same time period. ${ }^{33}$ All of these three essentially balladic poems are instances of remembered loss, suggesting that Mangan was not oblivious to the emotional potential of the shorter fourth line. Critics have often noted the pathos inherent in the shorter fourth line of the ballad stanza of Keats's 'La Belle Dame sans Merci', and a similar effect is arguably at work in Mangan's Irish stanza. As a result, one can say that the sense of loss that is present in the Wordsworthian and Schillerian intertexts is also tangible at a formal level. The 
distance separating the speaker from 'the blest hills yonder' in the seventh stanza of Mangan's poem may appear to be banished at the end of his text, but the form of the poem intimates that full presence is not attained.

To use Schiller's terminology, one could say that 'The Lovely Land' is a sentimental poem that presents itself as 'naïve'. The motivation for such dissimulation is not hard to imagine: the poem is meant to be a nationalist rallying cry in a time of trouble, and as such it necessarily traffics in idealisations of nation and landscape. Arguably the effects of an extra-literary genre are felt at this juncture. The ending of the poem is informed by the mechanics of the public oath, a speech genre very much in the air in Ireland during this decade. In Ireland the 184 os were marked by a strong drive towards teetotalism, and in her biography Ellen Shannon-Mangan shows how much Mangan deliberated over whether he should take Father Theobald Mathew's Total Abstinence Pledge. He also made public oaths of his political commitment, for instance in a letter to John Mitchell that was published in The United Irishman on 25 March, 1848. Such commitment may have been troubled by doubts and distractions, but it is in the nature of the oath to set aside any overt show of hesitation in favour of a clear statement of intent. In addition to Mangan's own biography, the use of an oath at this juncture can be understood in the context of Daniel Maclise's work. One of Maclise's most famous early paintings is The Installation of Captain Rock (1834), which was inspired by Thomas Moore's Memoirs of Captain Rock (1824). Both Maclise's painting and Moore's text are complex affairs, however, and in no way fit comfortably in with the radically nationalist tenor of Mangan's later work. In fact, Tom Dunne reads the former - with its burlesque depiction of a sensual and unruly gang of peasant insurrectionists - as 'mock-heroic, rather than heroic'. ${ }^{34}$

The oath is primarily committed towards the future, and Mangan's poem is indeed tacitly dedicated to an Ireland of the future. The ancient, then, is not only that which confirms the elevated nature of the Irish landscape but also concerns its destination. Antiquity for Mangan is here a dimension that transcends the classical landscapes of Poussin and Veronese, and also enters into Biblical terrain. The title of the poem, which may seem overly saccharine to a current readership, points in this direction. The phrase 'lovely land' crops up earlier in Mangan's oeuvre, in his 1839 poem 'My Home': there the speaker evokes a journey to 'a lovely Orient land, / . . to this my lovely land, / Where the sun at morning early / Rises, fresh, and young, and glowing. ${ }^{35}$ This poem pretends to be a translation of Karl Friedrich Gottlob Wetzel's 'Kennt ihr das schöne Eiland', but is in fact an original composition of Mangan's. The wording derives the Catholic version of the Bible that Mangan would have used - the Douay-Rheims Bible - where Jeremiah 3:19 reads as follows: 'But I said: How shall I put thee among the children, and give thee a lovely land, the goodly inheritance of the armies of the Gentiles?' The Promised Land is the lovely land. It is only this Bible version that uses this particular phrase, while most others English-language versions including the King James Version - use 'pleasant land'. So the phrasing might in fact provide something of a shibboleth for Catholic readers of Mangan. Such 
an identification of Ireland with the Promised Land of the Jews concurs with other passages in Mangan's writings. Best known is the concluding quatrain of his rendering of the Irish poem 'Kathaleen Ny-Houlahan': 'He, who over sands and waves led Israël along - / He, who fed, with heavenly bread, that chosen tribe and throng - / He, who stood by Moses, when his foes were fierce and strong - / May He show forth His might in saving Kathaleen Ny-Houlahan!'36

\section{The Round Tower and the Reclaiming of Exiles}

If the Douay-Rheims Bible might provide an understated way of reaching out to a certain audience, the poem is of course also very explicit in how it embraces a sense of Irishness which would have been shared with most of the readers of The Nation. The turning point of the poem is marked by an encounter with a specific architectural edifice: 'But what spy I? ... O, by noonlight! / 'Tis the same! - the pillar-tower / I have oft passed thrice an hour.' The reference to the 'pillar-tower' is notably brief, lacking the elaborateness of Moore's 'Let Erin Remember the Days of Old', which pictures a fisherman on Lough Neagh, catching sight of 'the round towers of other days / In the wave beneath him shining. ${ }^{37}$ A quick reading of 'The Lovely Land' might tempt one to believe that the passing reference to the tower is purely incidental, merely intended to spur a sense of recognition in the speaker. Could any familiar trait of the neighbourhood of the speaker have fulfilled the same function? Perhaps not, since it is vital that the encountered feature in the landscape should spark a sense of specifically national belonging.

Joep Leerssen has shown that pillar towers, or round towers as they are more commonly called today, were a vital and contentious fulcrum of Irish antiquarian interest during the nineteenth century. ${ }^{38}$ In 1845 , George Petrie - with whom Mangan had collaborated on the Ordnance Survey - finally published his Royal Irish Academy prize-winning essay on the historical origin of the round towers.

Petrie provided a positivist debunking of more fanciful theories, arguing that these were edifices primarily offering Christian monastic communities protection from external enemies. The same year, however, Denis Florence MacCarthy's 'The Pillar Towers of Ireland' was published in The Nation. MacCarthy's poem became a much-anthologised, popular favourite, and is far from circumspect in its speculation about the past of these edifices: 'the warm blood of the victim have these gray old temples drunk, / And the death-song of the druid and the matin of the monk'. ${ }^{39}$ Petrie's sober antiquarianism was coupled with artistic work such as his watercolour The Last Circuit of the Pilgrims at Clonmacnoise, Co. Offaly (1842) (ill. 5), where the round tower plays a central role in establishing the Irish setting. However striking their differences are, Petrie and MacCarthy share a sense of the distinctively Irish nature of round towers. ${ }^{40}$ Leerssen notes that the towers 'do not have any analogues in the standard typology of mainstream European architecture and are, therefore, largely sui generis and practically exclusively Irish'. ${ }^{41}$ Coupled with the backdrop of the lively interest in contemporary antiquarianism, evident for instance in the pages of The Nation, this uniqueness makes it 
thing as a 'Lovely Land'? Is there a suggestion here, then, that the 'Glorious birth of Mind and colour' celebrated by Mangan's poem is primarily a thing reflecting of mental glories? This would place it in the kind of Romantic territory established by Geoffrey Hartman's celebrated phenomenological reading of the Simplon Pass episode in Wordsworth's Prelude. ${ }^{42}$ The relative paucity of references to Irish landscape in Mangan's work in general might tempt one to embrace this hypothesis. At the same time, the poem does return - albeit vaguely and briefly - to the 'soil and skies' of Ireland in the penultimate stanza, and there is no evidence that this land is in any way belittled by its lack of distinctiveness compared to the environs immortalized by Veronese and Poussin.

When 'The Lovely Land' was reprinted in The Nation after Mangan's death, the editor described it as a 'beautiful descriptive poem' that was 'typical of poor Mangan's loving perception of the many scenic beauties of Ireland'. ${ }^{43}$ This rather rose-tinted view not only obscures the complexity of the poem, but also eschews any reference to the puzzling way in which the poem interacts with encroaching contextual features. As mentioned earlier, Mangan's collected oeuvre makes it hard, today, to speak confidently of his 'loving perception' of Irish scenic beauty. This, after all, is a man who - according to his unfinished autobiography - would confess: 'I hate scenery and suns. I see nothing in Creation but what is fallen and ruined. ${ }^{44}$ Further, there is not only no trace of a specific painting by Maclise that might have provided inspiration for 'The Lovely Land', but Irish landscape is indeed not something with which the mature Maclise had much truck. On 2 December, 1843, an article in The Nation by Thomas Davis on 'National Art' put its finger on part of the problem:

Ireland has had some great Painters - Barry and Forde for example, and many of inferior but great excellence; and now she boasts high names - Maclise, Hogan, and Mulready. But their works were seldom done for Ireland, and are rarely known in it. Our portrait and landscape Painters paint foreign men and scenes; and, at all events, the Irish people do not see, possess, and receive knowledge from their works. ${ }^{45}$

A stronger statement along these lines would be made by John Sproule, in connection with the Dublin Industrial Exhibition in 1853, when he 'sneered at Irishmen like Daniel Maclise and James Arthur O'Connor for living in England, who "transferring their allegiance to a strange soil ... soon forget the purer inspiration of their youth at home" '.46 Such a sceptical holding at an arm's length of Maclise (among others) is perhaps what one would expect, given that The Nation was a strongly nationalist newspaper. For Maclise had in fact left Cork for London at the age of 22, and in time his work for the Houses of Parliament would define him as quintessentially an artist of the British Empire. Although one seeks in vain for a consistently negative stance on his art in The Nation, the newspaper's letter section of 22 November, 1845, includes an interesting description of Maclise's position as seen from Ireland: 
Such pictorial, sculptured and written Illustrations of our history as Mr. Maguire's letter suggests must come sooner or later; but England has robbed us of many, to whom such a task would naturally belong. Maclise, the master of the magic pencil, Franklin, the true successor and rival of Albert Dürer, Shee, the poet-painter, the exquisite Rothwell - why are they not at home to make Irish history and Irish manners immortal upon canvas? ... There is but one why and because in our misfortunes. If we had a living country all these gifted men would be amongst us; and our 'artists in words' too. ${ }^{47}$

Mangan can be seen as pitching in for the national cause, assisting in making Ireland a more 'living country', by writing an ekphrastic poem where he acts as if Maclise had not left Ireland and its landscape behind. If 'England has robbed us', Mangan's act of restitution effectively amounts to robbing back the prestige of Maclise's art to his mother country.

It is a gesture that involves some dissimulation: Mangan pretends that Maclise is a nationalist painter of landscapes, in order to appropriate him firmly to the ideals of cultural nationalism (ill. 6). Insofar as Maclise still, in 1846, might be assumed to long for 'the blest hills yonder' of an independent and prosperous Ireland, the poem imagines the end of his exile. Here the emphatic and unquestioned distinctiveness of the round tower motif, together with its traditional permanence, might also be read as healing or occluding any sense of untrustworthy modernity in the public image of the London-based painter. There may indeed also be a more personal feint involved on Mangan's side: as Ciara Hogan has put it, Mangan's own nationalism was of an 'irresolute', rather than firm, character. ${ }^{48}$

Even more cautiously, Sean Ryder has commented that 'Mangan's political views evolved in response to the circumstances in which he wrote, worked, and published, and it is not always possible to judge the "sincerity" of any of the political sentiments expressed in his poems. ${ }^{49}$ Certainly, this reading has shown that 'The Lovely Land' is a complex affair. A poem of apparent naivety and spontaneity, it is in fact a strongly mediated performance. Its Irish nationalism only comes about through a complex interweaving of the classical and the biblical, even while it feeds on English and German precedent. Leerssen has contrasted 'nineteenth-century particularism', within Irish cultural nationalism, with the opposing idea 'that Ireland, like any nation, is part of the world at large, and that Irish nationality, like any nationality, is to be defined as part of, and not in contradistinction to, the world as a whole. ${ }^{50}$ Mangan's poem presents a scene of nationalist recognition that may seem particularist, but which, at closer inspection, reveals itself to be hard to comprehend without an awareness of a wide context. Similar complexity is at work on a generic level. Far from simply replicating a visual landscape, the genre of ekphrasis is in 'The Lovely Land' informed by a subtle combination of the mechanics of pastoral, translation, elegiac ballad, and oath. Word does not straightforwardly follow image, and is imbricated in not only other images - but also other words, both literary and extra-literary. In his light-hearted collection of epigrams and fragments titled 'A Sixty-Drop Dose of Laudanum', Mangan claimed that 'somehow I find that almost every thing that 
is natural in me is wrong also.' ${ }^{51}$ It would be an overstatement to say that everything that is natural in 'The Lovely Land' is wrong - but it would also be quite a stretch to say that this enthusiastic encomium to Irish landscape is purely and exclusively natural. 


\section{Notes}

1 All quotations from the poem refer to the following edition: James Clarence Mangan, Poems: 1845-1847 (Collected Works), ed. Jacques Chuto, Rudolf Patrick Holzapfel and Ellen Shannon-Mangan (Dublin: Irish Academic Press, 1997), 201-2. The poem can also be found in James Clarence Mangan, Selected Writings, ed. Sean Ryder (Dublin: University College Dublin Press, 2004), 230-1.

2 A key study is Richard P. Davis, The Young Ireland Movement (Dublin: Gill and Macmillan, 1987). For a short account of the movement's uneasy relations with Daniel O'Connell and its increasing radicalization, see Gearóid Ó Tuathaig, Ireland Before the Famine, 1798-1848 (Dublin: Gill and Macmillan, 2007 [1972]), 166-80.

3 Sean Ryder, 'Introduction', in James Clarence Mangan, Selected Writings, ed. Sean Ryder (Dublin: University College Dublin Press, 2004), 6. Building on the work of Fiona Stafford, Melissa Fegan has suggested that there is a suggestion of 'immersion in and internalization of English Romantic values and aesthetics', even while he twists this precedent in a subversive direction (“"Every Irishman is an Arab”: James Clarence Mangan’s Eastern "Translations”, Translation and Literature, no. 22 [2013], 210). In an otherwise enlightening article, Patricia Coughlan in 1986 contrasted the political and everyday stakes of Mangan's work with its deployment of 'the grand literary inheritance of high Romanticism, with its imperatives arising from the force of the individual will and sensibility' (Patricia A. Coughlan, "Fold over Fold, Inveterately Convolv'd": Some Aspects of Mangan's Intertextuality', in Anglo-Irish and Irish Literature: Aspects of Language and Culture, ed. Brigit Bramsbäck and Martin Croghan, vol. 2. Acta Universitatis Upsaliensis. Studia Anglistica Usaliensia no. 65. [Uppsala: The University of Uppsala, 1988], 198). More recent scholarship has however shown that these two tendencies are not exclusive of one another - since a notion of the everyday is central, for instance, to the achievement of Wordsworth - and I have therefore chosen not to distinguish between them here.

4 Edna Longley, 'No More Poems about Paintings?', in Edna Longley, The Living Stream: Literature and Revisionism in Ireland (Newcastle-Upon-Tyne: Bloodaxe, 1994), 227-51.

5 W. J. T. Mitchell, Iconology: Image, Text, Ideology (Chicago, IL: The University of Chicago Press), 1986.

6 'Maclise's Illustrations of Moore', The Nation, 29 November, 1845, 12. The article bears some similarity to work by Thomas Davis in The Nation, but was published after the latter's death on 16 September, 1845 . In the single scholarly discussion of 'The Lovely Land' of any length, David Lloyd frames his reading with a brief explication of Davis's essay on 'National Art' (published in The Nation on 2 December, 1843), which calls for an idealization of Irish history and landscape in the nationalist cause. Lloyd's reading centres on what he understands to be Mangan's ambivalence with regard to artistic representation: see David Lloyd, Nationalism and Minor Literature: James Clarence Mangan and the Emergence of Irish Cultural Nationalism (Berkeley, CA: University of California Press, 1987), 95-8. I quote from another part of Davis's important article later on in this essay.

7 'Maclise's Illustrations of Moore' (29 November, 1845), 12.

8 'Maclise's Illustrations of Moore' (6 December, 1845), 8.

9 The Nation, 22 November, 1845, 6. Interestingly, a little earlier in 1845 - on March 22 - a column in The Nation entitled 'Literary Intelligence' mentioned the forthcoming edition of Maclise's 
illustrations to Moore's melodies in the company of 'Mr. Petrie's long desired essay on the Round Towers of Dublin' and an edition of Mangan's poems.

10 'Sketches and Reminiscences of Irish Writers. No. IX. William Maginn, LL.D.', in James Clarence Mangan, Prose: 1840-1882, Correspondence (Collected Works), ed. Jacques Chuto et al. (Dublin: Irish Academic Press, 2002), 218.

11 See particularly the introduction to Jean-Luc Nancy, The Birth to Presence, trans. Brian Holmes et al. (Stanford: Stanford University Press, 1993).

12 James Clarence Mangan, Poems: 1848-1912, General Index (Collected Works), ed. Jacques Chuto, Tadhg Ó Dúshláine and Peter van de Kamp (Dublin: Irish Academic Press, 1999), 56.

13 Mangan, Poems: 1848-1912, 230.

14 James Clarence Mangan, Prose: 1832-1839 (Collected Works), ed. Jacques Chuto et al. (Dublin: Irish Academic Press, 2002), 129.

15 William Butler Yeats, Early Articles and Reviews, ed. John P. Frayne and Madeleine Marchaterre (New York: Scribner, 2004), 99.

16 Oona Frawley, Irish Pastoral: Nostalgia and Twentieth-Century Irish Literature (Dublin: Irish Academic Press, 2005), 43.

17 See Ellen Shannon-Mangan, James Clarence Mangan: A Biography (Blackrock: Irish Academic Press, 1996), 417.

18 Mangan, Poems: 1848-1912, 137-8.

19 Robert Welch writes the following of 'A Vision of Connaught in the Thirteenth Century', a poem published in The Nation one week prior to 'The Lovely Land': 'The poem appeared in the Nation on 11 July 1846 , when during the hot and unnaturally humid summer it was beginning to be apparent that the potato crop that year was to be a total failture' (Robert Welch, Irish Poetry from Moore to Yeats [Gerrards Cross: Colin Smythe, 1980], 108).

20 William Wordsworth, The Poems, ed. John O. Hayden, vol. 1 (Harmondsworth: Penguin, 1977), 523-9.

21 Mangan did not translate 'Die Götter Griechenlands', but shows familiarity with it in Mangan, Prose: $1832-1839,98$ and 268.

22 Mangan, Prose: 1832-1839, 81.

23 John Keats, Poems, ed. Gerald Bullett (London: Dent, 1974), 191.

24 Thompson quoted in James Kilroy, James Clarence Mangan (Lewisburg, PA: Bucknell University Press, 1970), 27.

25 James A. W. Heffernan, Museum of Words: The Poetics of Ekphrasis from Homer to Ashbery (Chicago and London: The University of Chicago Press, 1993), 14.

26 The editors of a recent selection of Mangan's verse point towards this problem, when their introductory note states that the poems 'appear as Mangan himself presented them, that is as originals or translations. However, the reader is invited to bear in mind that "translations" may be original poems, and vice versa' (Jacques Chuto et al., 'Editors' Note', xx, in James Clarence Mangan, Selected Poems, ed. Jacques Chuto et al. [Dublin: Irish Academic Press, 2003]).

27 Mangan, Prose: 1840-1882, 223.

28 The identification of Poussin as a master of sunlight, in stanza four, echoes Mangan's 1937 claim that 'Poussin thought it essential to the effective development of his Arcadia to represent the sunset as illuminating the looks of his shepherds' in Les Bergers d'Arcadie (Mangan, Prose: $1832-1839,128)$. 
29 Although such an understanding of translation is common, it is not uncontested: see chapter 6 of Peter Robinson, Poetry \& Translation: The Art of the Impossible (Liverpool: Liverpool University Press, 2010).

David Lloyd, 'James Clarence Mangan's Oriental Translations and the Question of Origins', Comparative Literature 38, no. 1 (1986), 26. Jacques Chuto writes that 'we believe that we are reading Wetzel translated by Mangan, whereas we are actually reading Mangan disguised as Wetzel' (Chuto quoted in Welch, Irish Poetry from Moore to Yeats, 84).

31 Murray's introduction is on the internet page 'Landscape and Irish Identity', accessed 8 August, 2013, http://www.crawfordartgallery.ie/exhibitions_Landscapes_of_Ireland.html. See also Finola O'Kane, Ireland and the Picturesque: Design, Landscape Painting, and Tourism, 1700-1840 (London: Yale University Press, 2013).

32 James Clarence Mangan, Poems: 1845-1847, 223.

33 For a reading sensitive to the form of the 'Ode to the Maguire', that also places it deftly in the context of the development of an Irish poetical idiom, see Matthew Campbell, 'Lyrical Unions: Mangan, O’Hussey and Ferguson', Irish Studies Review 8, no. 3 (2000), 325-38.

34 Tom Dunne, 'The Installation of Captain Rock', in Daniel Maclise, 1806-1870: Romancing the Past, ed. Peter Murray (Cork and Kinsale: Crawford Art Gallery and Gandon Editions, 2008), 104. Mangan, Poems: $1838-1844,120$

Mangan, Poems: 1838-1844, 240

Thomas Moore, Moore's Irish Melodies: The Illustrated 1845 edition, illustrated by Daniel Maclise (Mineola, NY: Dover, 2000), 38. Maclise's illustration to this song does not include the round tower motif.

38 See Joep Leerssen, Remembrance and Imagination: Patterns in the Historical and Literary Representation of Ireland in the Nineteenth Century (Cork: Cork University Press in association with Field Day, 1996), 108-43.

39 Lines 35-6 of 'The Pillar Towers of Ireland', in Denis Florence MacCarthy, Ballads, Poems, and Lyrics, Original and Translated (Dublin: James McGlashan, 1850), 142.

40 On the Clonmacnoise image, see Tom Dunne, 'Towards a National Art? George Petrie's Two Versions of The Last Circuit of Pilgrims of Clonmacnoise', in George Petrie (1790-1866): The Rediscovery of Ireland's Past, ed. Peter Murray (Cork and Kinsale: Gandon Editions, 2004), 126-36. Dunne touches briefly on Petrie's article on 'Remains at Monasterboice, County Louth', The Irish Penny Journal 1, no. 7 (August 1840), 49-50. Here Ireland's 'national individuality' is said to be embodied in 'green open landscapes' featuring 'the dark and ruined castle, seated on some rocky height, or the round tower, with its little parent church, in some sequestered valley, ... of such a scene we should say emphatically, This is Ireland!' Two weeks later, Mangan published his poem 'Woman of Three Cows' in the same journal.

41 Leerssen, Remembrance and Imagination, 108.

42 See Geoffrey H. Hartman, Wordsworth's Poetry, 1787-1814 (New Haven and London: Yale University Press, 1971), 33-69.

43 The Nation, 15 September, 1849, 11.

44 Mangan, Prose: 1840-1882, 239.

45 The Nation, 2 December 1843, 12.

46 Peter Somerville-Large, 1854-2004: The Story of the National Gallery of Ireland (Dublin: National Gallery of Ireland, 2004), 37. 
47 The Nation, 22 November $1845,10$.

48 Ciara Hogan, " "Lost Hero of the Past": Ruin, Wound, and the Failure of Idealism in the Poetry of James Clarence Mangan', Études Irlandaises, 35, no. 1 (2010). For an even more ironic reading of Mangan's nationalism, see Lloyd, Nationalism and Minor Literature.

49 Ryder, 'Introduction', 8.

50 Leerssen, Remembrance and Imagination, 231.

51 Mangan, Prose: 1832-1839, 274. 